\title{
Antimicrobial Activity of Some Satureja Essential Oils
}

Dilek Azaz ${ }^{\mathrm{a}}$, Fatih Demirci ${ }^{\mathrm{b}}$, Fatih Satıl ${ }^{\mathrm{a}}$, Mine Kürkçüoğlu ${ }^{\mathrm{b}}$ and Kemal Hüsnü Can Başer ${ }^{\text {** }}$

a Faculty of Science and Letters, Department of Biology, Balikesir University, 10100 Balikesir, Turkey

b Medicinal and Aromatic Plant and Drug Research Centre (TBAM), Anadolu University, 26470-Eskişehir, Turkey

* Author for correspondence and reprint request

Fax: +902223350127. E-mail: khcbaser@anadolu.edu.tr

Z. Naturforsch. 57c, 817-821 (2002); received May 16/July 1, 2002

Satureja sp., Essential Oil, Antimicrobial Activity

The genus Satureja is represented by fifteen species of which five are endemic and Satureja pilosa and $S$. icarica have recently been found as new records for Turkey. Aerial parts of the Satureja pilosa, S. icarica, S. boissieri and S. coerulea collected from different localities in Turkey were subjected to hydrodistillation to yield essential oils which were subsequently analysed by GC and GC/MS. The main constituents of the oils were identified, and both antibacterial and antifungal bioassays were applied. Carvacrol $(59.2 \%, 44.8 \%, 42.1 \%)$ was the main component in the oils of $S$. icarica, $S$. boissieri and $S$. pilosa, respectively. The oil of $S$. coerulea contained $\beta$-caryophyllene (10.6\%) and caryophyllene oxide $(8.0 \%)$ as main constituents.

\section{Introduction}

The genus Satureja (Lamiaceae) is represented in Turkey by fifteen species of which five are endemic (Davis, 1982; Tümen et al., 1998a).

Several Satureja species are locally known as "keklik otu", "kılıç kekik", "firubu”, "çatlı" or "kekik" in the regions where they grow and used as culinary or medicinal herbs in various regions of Turkey. Dried herbal parts constitute an important commodity for export. The uses of Satureja species have been reported in our previous works (Başer, 1995; Başer et al., 2001; Tümen et al., 1992; Tümen et al., 1993; Tümen and Başer, 1996; Tümen et al., 1997; Tümen et al., 1998a,b,c).

There is a large demand for fungicides for use in agriculture, food protection and medicine. Antifungal chemotherapy relies heavily on fungicides and many efforts have been made to standardize test procedures in order to increase reproducibility (Cormican and Pfaller, 1996). As a result, the National Committee for Clinical Laboratory Standards (NCCLS) proposed in 1997, an antifungal susceptibility test for yeast, with guidelines for macrodilution and microdilution methods. A modification of the said method (M38) for filamentous fungi appears promising and its standardization is reported to be in progress (Espinel-Ingroff, 1998).
However, since filamentous fungi do not grow as single cells, standardization appears to be more challenging in the case of unicellular yeast and bacteria (Hadecek and Greger, 2000).

Here, we report on the gas chromatographic (GC) and gas chromatography/mass spectrometric (GC/MS) analyses of the major constituents of the essential oils of four Satureja species: $S$. coerulea, S. icarica, S. pilosa and S. boissieri and their antibacterial and antifungal properties against common pathogenic and saprophytic fungi.

\section{Experimental}

\section{Plant material and isolation of the oils}

Information on the plant material used in this study is given in Table I. Air dried aerial parts were hydrodistilled for $3 \mathrm{~h}$ using a Clevenger-type apparatus. Percentage yields of oils calculated on moisture free basis are also indicated in Table I. Voucher specimens were deposited in the Herbarium of the Faculty of Pharmacy, Anadolu University (ESSE).

\section{Gas chromatography (GC)}

GC analysis using a Shimadzu GC-17A system. An CP-Sil 5 CB column $(25 \mathrm{~m} \times 0.25 \mathrm{~mm}$ inner 
diameter and $0.4 \mu \mathrm{m}$ film thickness) was used with nitrogen as carrier gas $(1 \mathrm{ml} / \mathrm{min})$. The oven temperature was kept at $60^{\circ} \mathrm{C}$ and programmed to $260^{\circ} \mathrm{C}$ for at a rate of $5^{\circ} \mathrm{C} / \mathrm{min}$, and then kept constant at $260^{\circ} \mathrm{C}$ for $40 \mathrm{~min}$. Split flow was adjusted at $50 \mathrm{ml} / \mathrm{min}$. Injector temperature was $250^{\circ} \mathrm{C}$. The percentages were obtanied from electronic integration measurements using flame ionization detection (FID, $250^{\circ} \mathrm{C}$ ).

\section{Gas chromatography / Mass spectrometry (GC/MS)}

A Shimadzu GCMS-QP5050A system, with CPSil 5 CB column $(25 \mathrm{~m} \times 0.25 \mu \mathrm{m}$ film thickness $)$ was used with helium as carrier gas. GC oven temperature was kept at $60^{\circ} \mathrm{C}$ and programmed to $260^{\circ} \mathrm{C}$ for at a rate of $5^{\circ} \mathrm{C} / \mathrm{min}$, and then kept constant at $260^{\circ} \mathrm{C}$ for $40 \mathrm{~min}$. Split flow was adjusted at $50 \mathrm{ml} / \mathrm{min}$. The injector temperature was at $250^{\circ} \mathrm{C}$. MS were taken at $70 \mathrm{eV}$. Mass range was between $\mathrm{m} / \mathrm{z} 30$ to 425 . Library search was carried out using the in-house "TBAM Library of Essential Oil Constituents". Relative percentage amounts of the separated compounds were calculated from FID chromatograms. $n$-Alkanes were used as reference points in the calculation of relative retention indices (RRI). The components identified in the oils are listed in Table I.

\section{Antimicrobial bioassay}

Microdilution broth susceptibility assay was used (Koneman et al., 1997). Stock solutions of essential oils were prepared in dimethylsulfoxide (DMSO). Serial dilutions of essential oils were prepared in sterile distilled water in 96-well microtiter plates. Freshly grown bacterial suspensions in double strength Mueller Hinton Broth (Merck) and yeast suspension of Candida albicans in yeast medium were standardised to $108 \mathrm{CFU} / \mathrm{ml}$ (McFarland No: 0.5). Sterile distilled water served as growth control. $100 \mu \mathrm{l}$ of each microbial suspension were then added to each well. The last row containing only the serial dilutions of antibacterial agent without microorganism was used as negative control. After incubation at $37^{\circ} \mathrm{C}$ for $24 \mathrm{~h}$ the first well without turbidity was determined as the minimal inhibitory concentration (MIC). Human pathogens used for this assay were obtained both from the Microbiology Department, Faculty of Sciences in Anadolu University and Microbiology
Department of Medical Faculty of Osmangazi University, Eskişehir (Table II).

\section{Fungal spore inhibition assay}

In order to obtain conidia, the fungi were cultured on Czapex Dox Agar medium (Merck) in $9 \mathrm{~cm}$ Petri dishes at $25^{\circ} \mathrm{C}$, for $7-10$ days. Harvesting was carried out by suspending the conidia in a $1 \%(\mathrm{w} / \mathrm{v})$ sodium chloride solution containing $5 \%$ (w/v) DMSO. The spore suspension was then filtered and transferred in to tubes and stored at $-20{ }^{\circ} \mathrm{C}$, accordingly to Hadacek and Greger (2000). The $1 \mathrm{ml}$ spore suspension was taken thereof, diluted in a loop drop until one spore could be captured (Hasenekoğlu et al., 1990).

One loop drop from the spore suspension was applied onto the centre of the Petri dish containing Czapex Dox Agar (Merck), Malt Extract Agar (Mast Diagnostics) and Potato Dextrose Agar (Acumedia) medium (Merck). $0.2 \mathrm{ml}$ of each essential oil was applied onto sterile paper disks ( $9 \mathrm{~mm}$ diameter) and placed in the Petri dishes and incubated at $25^{\circ} \mathrm{C}$ for $72 \mathrm{~h}$. Spore germination during the incubation period was followed using a microscope (Olympus BX50) in $8 \mathrm{~h}$ intervals. The fungi Aspergillus niger (BUB Czp.30), Penicillium sublateritium (BUB Czp. 69), P. canescens (BUB Czp. 38) and P. steckii (BUB Czp. 28) used for this assay were isolated from various soil samples and deposited in Balikesir University, Faculty of Science and Letters, Department of Biology (BUB), Balikesir, Turkey.

\section{Results and Discussion}

Water distilled essential oils from aerial parts of S. coerulea, S. icarica, S. pilosa and S. boissieri collected from four different localities in Turkey have been analysed by means of GC and GC/MS. The resulting main components of the oils are shown in Table I along with other collections and yield information.

The analyses showed that carvacrol $(42.1 \%-$ $59.2 \%$ ) was the main component in the oils of $S$. icarica, S. pilosa and S. boissieri. Other major components were identified as $p$-cymene $(8.1 \%-$ $35.5 \%)$ and borneol $(4.5 \%-6.3 \%)$, besides other monoterpenes. In contrast, S. coerulea contained mainly sesquiterpenes such as $\ddot{i}$-caryophyllene $(10.6 \%)$, germacrene D $(4.7 \%)$, and caryophyllene 
Table I. Information on collection of Satureja sp. and essential oil compositions.

\begin{tabular}{|c|c|c|c|c|c|c|}
\hline Satureja $\mathrm{sp}$ & Collection site and date & ESSE $^{a}$ & $\begin{array}{l}\text { Oil } \\
\text { Yields } \\
(\%)\end{array}$ & $\mathrm{RRI}^{\mathrm{b}}$ & Main components & $(\%)^{\mathrm{c}}$ \\
\hline $\begin{array}{l}\text { S. boissieri } \\
\text { Hausskn. ex Boiss. }\end{array}$ & $\begin{array}{l}\text { C7: Adiyaman } \\
30.09 .2001\end{array}$ & 13985 & 1.1 & $\begin{array}{l}1273 \\
1007 \\
1048 \\
1276\end{array}$ & $\begin{array}{l}\text { carvacrol } \\
p \text {-cymene } \\
\gamma \text {-terpinene } \\
\text { thymol }\end{array}$ & $\begin{array}{l}44.8 \\
35.5 \\
6.5 \\
2.3\end{array}$ \\
\hline $\begin{array}{l}\text { S. coerulea } \\
\text { Janka in Velen. }\end{array}$ & $\begin{array}{l}\text { A1: Kırklareli: Dereköy } \\
29.10 .2001\end{array}$ & 13983 & 0.6 & $\begin{array}{l}1422 \\
1565 \\
1151 \\
1471 \\
1022 \\
1374 \\
1563\end{array}$ & $\begin{array}{l}\beta \text {-caryophyllene } \\
\text { caryophyllene oxide } \\
\text { borneol } \\
\text { germacrene D } \\
\text { limonene } \\
\beta \text {-bourbonene } \\
\text { spathulenol }\end{array}$ & $\begin{array}{l}10.6 \\
8.0 \\
6.3 \\
4.7 \\
4.3 \\
3.6 \\
3.0\end{array}$ \\
\hline $\begin{array}{l}\text { S. icarica } \\
\text { P. H. Davis }\end{array}$ & $\begin{array}{l}\text { A1: Danakkale: Gökçeada } \\
\text { 23.09.2001 }\end{array}$ & 13984 & 0.8 & $\begin{array}{l}1273 \\
1007 \\
1151 \\
1048 \\
1218\end{array}$ & $\begin{array}{l}\text { carvacrol } \\
p \text {-cymene } \\
\text { borneol } \\
\gamma \text {-terpinene } \\
\text { methyl carvacrol }\end{array}$ & $\begin{array}{l}59.2 \\
15.7 \\
4.5 \\
4.4 \\
2.0\end{array}$ \\
\hline S. pilosa Velen. & $\begin{array}{l}\text { B1: Balıkesir: Edremit } \\
\text { 22.09.2001 }\end{array}$ & 13986 & 0.4 & $\begin{array}{l}1273 \\
1007 \\
1238 \\
1151 \\
1490 \\
1218\end{array}$ & $\begin{array}{l}\text { carvacrol } \\
p \text {-cymene } \\
\text { geraniol } \\
\text { borneol } \\
\beta \text {-bisabolene } \\
\text { methyl carvacrol }\end{array}$ & $\begin{array}{l}42.1 \\
8.1 \\
7.6 \\
4.7 \\
4.3 \\
3.1\end{array}$ \\
\hline
\end{tabular}

a ESSE: Acronym of the Herbarium of the Faculty of Pharmacy, Anadolu University, Eskişehir, Turkey.

b RRI: Relative retention indices calculated against $n$-alkanes on non-polar column (CP Sil5CB).

c $(\%)$ : Relative percentage from FID.

oxide $(8.0 \%)$ as main components (See also Table I).

In an earlier work, the essential oil of S. icarica was reported to contain carvacrol $(52.0 \%-$ $56.0 \%)$, borneol $(5.2 \%-5.8 \%), \gamma$-terpinene $(5.8 \%$ - $6.9 \%)$, p-cymene $(13.1 \%-17.0 \%)$ as main constituents. The essential oil of $S$. coerulea was reported to contain $\beta$-caryophyllene $(10.3 \%-$ $12.2 \%)$, caryophyllene oxide $(3.9 \%-5.7 \%)$, borneol $(4.4 \%-8.2 \%), 1,8$-cineole $(0.1 \%-1.5 \%)$, limonene $(0.3 \%-5.1 \%)$ and germacrene D $(12.8 \%-20.6 \%)$, and the essential oil of S. pilosa was reported to contain carvacrol $(5.1 \%-53.5 \%)$, $p$-cymene $(4.7 \%-17.4 \%)$, geraniol $(1.2 \%-4.5 \%)$, and borneol $(1.0 \%-8.8 \%)$ being the main constituents as investigated by Tümen et al. (1998a and 1998c). However, to the best of our knowledge, the essential oil composition of $S$. boissieri has not previously been investigated.

In our previous work (Başer et al., 2001), antibacterial activity of the essential oils of $S$. wiedemanniana obtained from various samples was shown. Carvacrol and thymol were shown to in- hibit pathogenic microorganisms. Furthermore, antimicrobial activities of different Satureja species were shown in other previous studies (Müller-Riebau et al., 1995; Akgül and Kıvanç, 1988; Kıvanç and Akgül, 1989).

In this present study, using the microdilution broth assay (Koneman et al., 1997), the essential oil of S. pilosa showed a minimal inhibitory concentration value of $31.25 \mu \mathrm{g} / \mathrm{ml}$ against the pathogenic yeast Candida albicans. The other oils tested were also found as active against $C$. albicans in various inhibitory concentration ranges (see Table II). Pseudomonas aeruginosa was best inhibited by the oil of S. icarica and the other oils tested also showed inhibitory activities. The pathogen Enterobacter aerogenes was inhibited by both $S$. pilosa and $S$. icarica essential oils with a MIC value of $62.5 \mu \mathrm{g} / \mathrm{ml}$, stronger than the standard Chloramphenicol. Salmonella typhimurium was inhibited by all oils except for S. coerulea as good as the standard antimicrobial agent. As a general result, all the bacteria assayed showed inhibition when tested against the Satureja oils (see Table II). 


\begin{tabular}{llccccc}
\hline Microorganisms & Source & A & B & C & D & St \\
\hline Escherichia coli & ATCC 25292 & 125 & 125 & 125 & 62.5 & 62.5 \\
Staphylococcus aureus & ATCC 6538 & 62.5 & 125 & 125 & 62.5 & 7.81 \\
Pseudomonas aeruginosa & ATCC 27853 & 125 & 125 & 125 & 62.5 & 250 \\
Enterobacter aerogenes & NRRL 3567 & 125 & 125 & 62.5 & 62.5 & 125 \\
Proteus vulgaris & NRRL 123 & 125 & 125 & 62.5 & 62.5 & 31.25 \\
Salmonella typhimurium & NRRL 4420 & 62.5 & 125 & 62.5 & 62.5 & 62.5 \\
Candida albicans & OGU & 62.5 & 62.5 & 31.25 & 62.5 & $125^{*}$ \\
Aspergillus niger & BUB Czp. 30 & - & - & - & - & $+*$ \\
Penicillium sublateritium & BUB Czp. 69 & - & - & - & - & $+*$ \\
Penicillium canescens & BUB Czp. 38 & + & + & + & + & $+*$ \\
Penicillium steckii & BUB Czp. 28 & - & - & - & - & $+*$ \\
\hline
\end{tabular}

Table II. Antimicrobial activity (MIC) of Satureja essential oils.

When the fungal spore inhibition assay was applied to the oils, observation during the three-day incubation period showed that Penicillium canescens spores were strongly inhibited, while germination of Aspergillus niger, Penicillium steckii and $P$. sublateritium were not inhibited by the tested samples.

In conclusion, the essential oil compositions when compared to previous studies (Tümen et al., $1998 \mathrm{a}, \mathrm{b})$ have been confirmed. In addition, it is evident that these antimicrobial activities do not result only from monoterpenes such as carvacrol and thymol as reported in the previous work (Başer et al., 2001) but also $S$. coerulea essential oil rich in sesquiterpenes, which also displayed activity. It may be worthwhile to investigate the individual components in antibacterial and antifungal assays.

\section{Acknowledgements}

This study was partially supported by the Research Fund of Anadolu University (AÜAF 980312).
Akgül A. and Kıvanç M. (1988), Inhibitory effects of six Turkish Thyme-like spices on some common foodborne bacteria. Die Nahrung 32, 201-203.

Başer K. H. C. (1995), Essential Oils from aromatic plants which are used as herbal tea in Turkey, In: Flavours, Fragrance and Essential Oils. Proceedings of the 13th International Congress of Flavours, Fragrances and Essential Oils (Başer K. H. C., ed.). AREP Publications, Istanbul, Turkey, pp. 67-79.

Başer K. H. C., Tümen, G., Tabanca, N. and Demirci, F. (2001), Composition and antibacterial activity of the essential oils from Satureja wiedemanniana (Lallem.) Velen, Z. Naturforsch. 56 c, 731-738.

Başer K. H. C., Özek T., Kırımer N. and Tümen G. (2002), A comparative study of the essential oils of wild and cultivated Satureja hortensis. J. Essent. Oil Res. (In press).

Cormican M. D. and Pfaller M. A. (1996), Standardization of antifungal susceptibility testing. J. Antimicrob. Chemother. 38, 561-578.

Davis P. H. (1982), Flora of Turkey and the East Aegean Islands. Vol. 7, Edinburgh University Press, Edinburgh, p. 319
Espinel-Ingroff A. (1998), In vitro activity of the new triazole: voriconazole (UK-109,496) against opportunistic filamentous and dimorphic fungi and common and emerging yeast pathogens. J. Clin. Microbiol. 36, 198-202.

Hadecek F. and Greger H. (2000), Testing of antifungal natural product: methodologies, comparability of result and assay choice. Phytochem. Anal. 11, 137147.

Hasenekoğlu İ. (1990), Mikrofunguslar İçin Laboratuar Tekniği (= Laboratory Techniques for Microfungi), Atatürk University, Erzurum, Türkiye.

Kıvanç M. and Akgül A. (1989), Inhibitory effects of spice essential oil on yeast. Turk. J. Agric. For. 13, 68-71.

Koneman E. W., Allen S. D., Janda W. M., Schreckenberger P. C. and Winn W. C. (1997), Color Atlas and Textbook of Diagnostic Microbiology. Lippincott-Raven Publ., Philadelphia, pp. 785-856.

Müller-Riebau F., Beger B. and Yegen O. (1995), Chemical composition and fungitoxic properties to phytopathogenic fungi of essential oils selected aromatic plants growing wild in Turkey. J. Agric. Food Chem. 43, 2262-2266. 
Tümen G., Sezik E. and Başer K. H. C. (1992), The essential oil of Satureja parnassica Heldr. \& Sart. ex Boiss. subsp. sipyleus. Flav. Fragr. J. 7, 43-46.

Tümen G., Başer K. H. C. and Kırımer N. (1993), The essential oil of Satureja cilicica P. H. Davis. J. Essent. Oil Res. 5, 547-548.

Tümen G. and Başer K. H. C. (1996), The essential oil of Satureja spicigera (C. Koch) Boiss. from Turkey. J. Essent. Oil Res. 8, 57-58.

Tümen G., Kırımer N. and Başer K. H. C. (1997), The essential oils of Satureja L. occurring in Turkey. In: Proceeding of the $27^{\text {th }}$ International Symposium on Essential Oils (Franz C. H., Mathe A. and Buchbauer
G., eds.). Allured Publishing Corporation, Vienna, Austria, pp. 250-254

Tümen G., Kırımer N., Ermin N. and Başer K. H. C. (1998a), The essential oils of two new Satureja species for Turkey, S. pilosa and S. icarica. J. Essent. Oil Res. 10, $524-526$.

Tümen G., Kırımer N., Ermin N. and Baser K. H. C. (1998b), The essential oil of Satureja cuneifolia. Planta Med. 64, 81-83.

Tümen G., Başer K. H. C., Demirci B. and Ermin N. (1998c), The essential oils of Satureja coerulea Janka and Thymus aznavourii Velen. Flav. Fragr. J. 13, 6567. 